\title{
BACTERIAL ANALYSIS OF ROOF-HARVESTED RAINWATER AND THEIR IMPLICATIONS TO PUBLIC HEALTH IN THE CARIBBEAN ISLAND OF ANGUILLA
}

\author{
Tiwari BR, ${ }^{1}$ Khuc $T,{ }^{2}$ Abidin $Z,{ }^{2}$ Gul $S,{ }^{2}$ Trofort $M,{ }^{2}$ lliou $C^{2}$
}

${ }^{1}$ Department of Microbiology and Immunology, American University of Barbados School of Medicine, Wildey, Saint

Michael, BB 14007 Barbados and 2Department of Microbiology, Saint James School of Medicine, Anguilla, BWI

\begin{abstract}
Anguilla is a dry to semi-arid island in the Caribbean where the majority of residents rely on roof-harvested rainwater. The objective of this study was to assess the presence of indicator coliform bacteria and associated health risk to the consumer in Anguilla. Rooftop rain water harvested samples were collected from 86 homes. Bacterial count was done by membrane filtration and culture on Difco Modified mTEC Agar and Hach m-ColiBlue24 agar. Bacteria grown on agar plates were counted by using darkfield colony counter. All owners or residents were interviewed for water use related gastroenteritis. Coliform bacteria were grown in 88.4\% (76/86) samples with very few colonies to confluent growth of fecal $E$. coli, non-fecal $E$. coli and coliform other than E. coli. Results indicated that the majority of the samples contain the mixture of different coliform bacteria. Household survey revealed the majority of the households drink unpotable roof harvested rain water without any treatments and have the history of at least one episode of gastroenteritis-like illness during the past year. Our result is suggestive of that coliform bacterium detected in roof-harvested rainwater throughout Anguilla poses a potential health risk to the consumers and requires proper treatment for consumption.
\end{abstract}

\section{KEYWORDS}

Roof harvested rain water, thermotolerant Escherichia coli, coliform bacteria, public health risk, Anguilla Island

\section{CORRESPONDING AUTHOR}

Dr. Birendra Raj Tiwari,

Department of Microbiology and Immunology,

American University of Barbados School of Medicine,

Wildey, Saint Michael, BB 14007 Barbados;

Email: tiwari.birendra58@gmail.com

Orcid ID: https://orcid.org/0000-0003-4654-8197

DOI: https://www.doi.org/10.3126/nmcj.v23i1.36235 


\section{INTRODUCTION}

Roof-harvested rain water is the main source of water supply in arid and semi-arid regions of the world; this poses a risk of gastroenteritis and other opportunistic infections. ${ }^{1-5}$ Thermotolerant Escherichia coli (fecal E. coli), non-fecal E. coli and coliform other than E. coli are considered as indicators of pathogens in drinking water. ${ }^{6-10}$

Anguilla is one of the sparsely populated dryto-semi-arid Leeward islands in the northerly Lesser Antilles of the Caribbean region and has no any natural sources of fresh water. ${ }^{11}$ Majority of residents of Anguilla rely on roof harvested rain water for drinking which is probably contaminated with bacterial pathogens. ${ }^{12}$ Therefore, the objective of this study was to assess the contamination of indicator bacteria in roof-harvested rain water in Anguilla. The study also aimed to find out if there are any associated health risks due to consuming this water.

\section{MATERIALS AND METHODS}

Sample collection and Ethical approval: The sampling was done during the months of September and October 2018 by selecting the 86 households using roof-harvested rain water in 10 different locations of the island. Ethical approval was obtained from Saint James School of Medicine Anguilla Campus Research Committee. Written informed consent was taken from each house owner before collection of samples. A brief questionnaire was filled out regarding the information for consumption habits and safety practices such as cleaning, disinfection of cistern, and filtration of water before pouring into cistern. Additionally, information related to any waterborne illness was obtained if they have experienced in the past year. Two water samples were collected from the kitchen tap in 100-ml sterile bottles opening the tap for a minimum of 2-3 minutes to flush the water or to clear the water lines. Immediately after collection the bottles were sealed, labeled, placed into chillers with ice packs to maintain a constant temperature of $4^{\circ} \mathrm{C}$ and to protect from sun light and were carried to the Anguilla Water Laboratory. All the samples were cultured within 6 hours by following the United States Environmental Protection Agency protocols for sample collection, transport, storage, sterilization and processing. ${ }^{13}$
Bacterial culture: Agar plates were prepared by dissolving the hydroscopic powder of modified mTEC Agar for thermotolerant $E$. coli according to manufacturer instructions (Becton, Dickinson and Co, Sparks, MD). Briefly, the agar was dissolved by boiling on a hot plate and autoclaved at $121^{\circ} \mathrm{C}$ for 15 minutes and cooled to $50^{\circ} \mathrm{C}$ in water bath. About $25 \mathrm{ml}$ of the medium was dispensed into sterile $90 \mathrm{~mm}$ Petri dish and allowed to solidify at room temperature. The plates were then stored at $4^{\circ} \mathrm{C}$ until use. Premade Hach m-ColiBlue24 (Hach Company, Loveland, Co) broth in ampules was used to detect non-fecal $E$. coli and coliform other than E. coli. The ampules was opened aseptically and the content was carefully poured uniformly into the petri dish with absorbent pad.

Six membrane filter funnels (Thermo Scientific, Waltham, MA) were attached to six chamber Gast vacuum setup. Flamed forceps dipped in alcohol were used to remove the $0.45-\mu \mathrm{m}$ Millipore membrane filters (Thermo Scientific, Waltham, MA) from packet and inserted into filter funnels, $100 \mathrm{ml}$ of collected samples were poured into each funnel accordingly. Agar plates were then labeled with sample code numbers and placed adjacently to the funnel. After Gast vacuum was turned on and allowed the water sample to filter through the membrane. Membrane filters were removed and placed on the surface of the agar top without bubbles. A separate membrane was used for different samples from the same house. The modified mTEC agar plates were incubated at $45.7^{\circ} \mathrm{C}$ to detect the thermotolerant $E$. coli, m-ColiBlue24 broth in plate for non-fecal $E$. coli and coliform other than $E$. coli were incubated at $37^{\circ} \mathrm{C}$ for 24 hours. Control plates were incubated along with the test plates for each day of sampling to rule out the contamination.

Bacterial identification and quantification: The isolated organisms were identified following the United States Environmental Protection Agency protocols Hach20 Water Analysis Handbook 5th edition guidelines. ${ }^{14}$ In order to estimate the bacterial quantity, colonies were counted based on corresponding color codes by using a QUEBEC Darkfield Colony Counter (AMETEK, Inc.1100 Cassatt Road Berwyn, PA). Thermotolerant E.coli was identified as bluish-purple colonies on Difco Modified mTEC Agar plates whereas non-fecal E. coli and total coliform bacteria were identified as blue and red colonies respectively on m-ColiBlue 24 broth absorbent pad.

Oxidase test was performed following $\mathrm{m}$-ColiBlue24 broth protocol to estimate actual 
number of total coliform, because a few noncoliform bacteria (such as Pseudomonas spp. and Aeromonas spp.) can grow on m-ColiBlue24 broth and produce red colonies. Pseudomonas spp. and Aeromonas spp. are oxidase-positive, whereas all coliform bacteria are oxidasenegative. Therefore, the oxidase test is helpful to confirm which red colonies are total coliforms. All the findings were then recorded.

A brief questionnaire survey was conducted from the all the 86 households. Residents living at least for one year in the particular house under survey were interviewed regarding their practices for filtration, cleaning, disinfection and health related calamities associated by consuming roof-harvested rainwater.

\section{RESULTS}

A total of $88.4 \%(76 / 86)$ water samples were found contaminated with coliform bacteria. Thermotolerant $E$. coli was detected in 43 (56.6\%) of samples. Non-fecal $E$. coli and other coliform were detected in $49(64.5 \%)$ and $67(88.1 \%)$ samples, respectively (Table 1). By assessment
Table 2: Composition of coliform bacteria presenting in different samples

\section{Composition of coliform bacteria}

Samples $n$ (\%)

Mixed growth of all

coliforms

$31(40.8 \%)$

Coliforms other than E. coli

$17(22.4 \%)$

Non-fecal E. coli + coliform other than $E$. coli

$13(17.1 \%)$

Thermotolerant $E$ coli + coliforms other than $E$. coli

$6(7.9 \%)$

Thermotolerant E. coli only

Non-fecal E. coli only

Thermotolerant E. coli + non-fecal E. coli

Total $76(88.4 \%)$

\section{Table 1: Number of coliform, colony forming unit (CFU) which were grown in roof} harvested rain water samples from households

\begin{tabular}{lccc|}
$\begin{array}{l}\text { Coliform counts } \\
\text { CFU/100ml }\end{array}$ & $\begin{array}{c}\text { Thermotolerant } \boldsymbol{E} \text {. coli } \\
\text { (only) }\end{array}$ & $\begin{array}{c}\text { Non-fecal } \boldsymbol{E} \text {. coli } \\
\leq 10\end{array}$ & $\begin{array}{c}\text { Coliform other than } \\
\boldsymbol{E} \text {. coli }\end{array}$ \\
$11-200$ & $23(30.3 \%)$ & $29(38.2 \%)$ & $8(10.5 \%)$ \\
Confluent growth & $17(22.4 \%)$ & $15(19.7 \%)$ & $30(39.5 \%)$ \\
Total & $3(3.9 \%)$ & $5(6.6 \%)$ & $29(38.2 \%)$ \\
\hline
\end{tabular}

of bacterial composition, 31 (40.8\%) samples were found to be co-contaminated with all 3 indicator bacteria (Table 2). The highest number of samples showed moderate growth (10-300 CFU/100 ml) and moderate number of samples showed very confluent growth (Table 1).

Coliform counts in culture revealed growth (Table 1) in 76 samples with very few to confluent kinds of colonies, 10 samples did not show any growth. Thermotolerant $E$. coli (fecal E. coli) grew in 43 samples, in which 23 showed low-level contamination ( $\leq 10 \mathrm{CFU} / 100 \mathrm{ml}), 17$ showed moderate level contamination and 3 showed confluent growths, indicating heavy contamination. Similarly, 49 samples revealed non-fecal $E$. coli in which 29 indicated lowlevel contamination, 15 indicated moderate level contamination and 5 indicated heavy contamination. Furthermore, 67 samples were positive for coliform other than $E$. coli, in which 8 samples showed low level of contamination, 30 showed moderate level contamination and 29 samples confluent growth indicating heavy level of contamination.

We analyzed the bacterial composition in different samples. Table 2 shows mixed growth of thermotolerant $E$. coli, non-fecal $E$. coli and coliforms other than $E$. coli in 31 samples; only coliform other than E.coli were grown in 17 samples, coliform other than $E$. coli particularly 
represent enteric bacteria (Enterococcus spp., Proteus spp., Klebsiella spp., Enterobacter spp., and Citrobater spp.). Mixed growth of $E$. coli and coliform other than $E$. coli was noted in 13 samples, similarly mixed growth of thermotolerant $E$. coli and coliform other than $E$. coli was noted in 6 samples. Only non-fecal $E$. coli, thermotolerant $E$. coli, mixed growth of thermotolerant $E$. coli and non-fecal $E$. coli were also noted in few samples. Results indicated that the majority of the samples contain the mixture of different coliform bacteria.

Household survey: Our brief survey revealed that none of the households has installed a filter system on the run-off to the cistern; similarly, none of them were disinfecting water with chlorine. In total, 66 households (76.7.0\%) drink only unpotable roof-harvested rainwater. Only $20(23.2 \%)$ households are cleaning the cisterns every 1-2 years and only 4 (4.6\%) households are cleaning it 2-6 month, respectively. Overall, 30 (45.4\%) people out of 66 who regularly drink unpotable roof harvested rain water without any treatments such as filtration or boiling have the history of at least one episode of gastroenteritis-like illness during the past year, whereas only $2(10.0 \%)$ people out of 20 who only drink bottled water have a history of gastroenteritis in the past year. However, none of them have a history of hospitalization due to gastroenteritis. People drinking unpotable cistern water and those drinking only bottled water were residents of different households.

\section{DISCUSSION}

Roof-harvested rain water is the main source of water supply in arid and semi-arid regions of the world and as this poses a risk of gastroenteritis and other opportunistic infections $^{1-5}$ we assessed roof-harvested rainwater for presence of fecal indicator bacteria in households of the island country of Anguilla using the membrane filtration technique. We used membrane filtration technique as this is considered to be one of the best quantitative methods to enumerate the bacterial number in drinking water. ${ }^{15}$ Similarly, we also employed the Difco Modified mTEC agar and $\mathrm{m}$-ColiBlue24 broth as they are the best medium to detect thermotolerant $E$. coli, nonfecal $E$. coli and coliform other than $E$. coli in drinking water. ${ }^{16}$ To the best of our knowledge, this is the first study concerning the extent of bacterial contamination in roof-harvested rain water from the country of Anguilla. Majority of water samples have shown contamination with coliform bacteria. Detection of fecal E. coli in over half of the samples (56.6\%) is the evidence of contamination of roof-harvested rainwater with human waste. Thermotolerant E. coli (fecal E. coli), non-fecal E. coli and coliform other than $E$. coli are considered as indicators of pathogens in drinking water. ${ }^{6-10}$ Our results indicated that roof-harvested rainwater did not meet the acceptable quality standard, therefore, is not recommended for drinking without proper treatment. These results are supported by several previous studies carried in different countries. ${ }^{17,18}$

In this study, $76.7 \%$ of the household residents mentioned that they utilize the roof-harvested rainwater for both daily sanitary needs and personal consumption. However, none of them were aware about the necessity of filtration and chlorine disinfection of drinking water. Our study revealed that only $28.0 \%$ of the households remove the debris and clean the cistern regularly. With regards to comparison between different locations throughout the island we did not find any definite difference in terms of microbial contamination status of the cistern water. East and West parts of the island quantitatively represented equal number of coliform colonies (in this study, a few samples contained bacteria that were too numerous to count introducing the potential errors for exact CFU quantity in the samples). The results indicated potential health risks due to the consumption of this non-potable water; $45.0 \%(30 / 66)$ of respondents drinking cistern water without treatment have a history of gastroenteritis-like illness in the past year. On the other hand, $10.0 \%(2 / 20)$ of respondents of those who only drink bottled water also have history of gastroenteritis-like illness in the past year. Our results correlate with other studies, who suggested the potential health related risk by the consumption of roof-harvested rainwater without proper treatment. ${ }^{19,20}$ Due to constrains of resources and laboratory facilities we were only able to assess the indicator bacteria within cistern water at a quantitative level. A more thorough study should include analysis of all potential microbial pathogens using metagenomics and other DNA testing would provide several other bacterial pathogens in the roof-harvested rainwater. In a review, Lye ${ }^{2}$ identified the diseases attributed to the consumption of untreated rainwater include bacterial diarrheas due to Salmonella and Campylobacter, bacterial pneumonia due to Legionella, botulism due to Clostridium, tissue helminthes and protozoal diarrheas 
from Giardia and Cryptosporidium. However, in this study, we did not examine the specific diarrheagenic pathogens as reviewed by Lye. ${ }^{2}$

Our results indicated that thermotolerant E. coli, non-fecal $E$. coli, and other coliform bacteria are widely dispersed in roof-harvested rainwater throughout the island of Anguilla. The water samples did not meet acceptable standards, and therefore are not recommended for drinking without proper treatment. Our results also revealed fecal bacterial contaminations posed a potential health risk to the consumers. The lack of cleaning, filtration and disinfection of the harvested water is the cause of fecal bacterial contamination, we recommend to residents to carry out proper treatment processes before consuming harvested rainwater.

\section{ACKNOWLEDGEMENTS}

We are very thankful to the Anguilla Water Laboratory, The Department of Health Protection, and Government of Anguilla for providing laboratory platform to this study. This study was supported by Saint James School of Medicine, Anguilla Campus research fund 2018.

\section{REFERENCES}

1. Ahmed W, Goonetilleke A, Gardner T. Implications of fecal indicator bacteria for the microbiological assessment of roof-harvested rainwater quality in Southeast Queensland, Australia. Can J Microbiol 2010; 56: 471-9. [PubMed].

2. Lye DJ. Health risks associated with consumption of untreated water from household roof catchment systems. J Amer Water Resources Assoc 2002; 38: 1301-6. [JAWRA]

3. Simmons G, Jury S, Thornley C, Harte D, Mohiuddin J, Taylor M. Legionnaires' disease outbreak: a water blaster and roof collected rainwater systems. Water Res 2008; 42: 144958. [PubMed].

4. Abbasi T, Abbasi SA. Sources of pollution in rooftop rainwater harvesting systems and their control. Crit Rev Environ Sci Technol 2011; 41: 2097-2167. [Crit Rev Environ Sci Technol]

5. Daoud AK, Swaileh KM, Hussein RM, Matani M. Quality assessment of roof-harvested rainwater in the West Bank, Palestinian Authority. J Water Health 2011; 9: 525-33. [PubMed]

6. Heyworth JS, Glonek G, Maynard EJ, Baghurst PA, Finlay-Jones J. Consumption of untreated tank rainwater and gastroenteritis among young children in South Australia. Int'l J Epidemiol 2006; 35: 1051-8. [PubMed]

7. Ahmed W, Vieritz A, Goonetilleke A, Gardner T. Health risk from the use of roof-harvested rainwater in Southeast Queensland, Australia, as potable or nonpotable water, determined using Quantitative Microbial Risk Assessment. Appl Environ Microbiol 2010; 76: 7382-91. [PubMed]

8. Dobrowsky PH, De Kwaadsteniet M, Cloete TE, Khan W. Distribution of indigenous bacterial pathogens and potential pathogens associated with roof-harvested rainwater. Appl Environ Microbiol 2014; 80: 2307-16. [PubMed]

9. Collins A. Theophillus P, Saphurah $\mathrm{N}$ et al. Roof-harvested rain water is a potential source of bacteria associated diarrhea in a peri-urban Southern Uganda setting: crosssectional study. Int'l J Devt Res 2017; 7: 164948. [ijdr]

10. WHO. Guidelines for Drinking Water Quality, $4^{\text {th }}$ edition, Geneva 2017.

11. Tamara HS. Freshwater resources in the insular Caribbean: an environmental perspective. Caribbean Studies 2012; 38: 63-93. [Caribbean studies]

12. WHO. Guidelines for Drinking-water Quality, $3^{\text {rd }}$ edition incorporating the first and second addendum, Geneva 2008.

13. Robin KO. Method 1603: Escherichia Coli (E. coli) in water by membrane filtration using modified membrane - thermotolerant Escherichia coli agar (modified MTEC). US Environmental Protection Agency Office of Water 2002. [NSCEP]

14. Hatch Water Analysis Guide 2013, $1^{\text {st }}$ edition, 2013. [HACH]

15. Kerry H, Brandon R, Monique W et al. A global review of the microbiological quality and potential health risks associated with roofharvested rainwater tanks. npj Clean Water 2019; 2: 1-18. [npj clean water]

16. Grant MA. A new membrane filtration medium for simultaneous detection and enumeration of Escherichia coli and total coliforms. Appl Environ Microbiol 1997; 63: 3526-30. [PubMed]

17. Levesque B, Pereg D, Watkinson E et al. Assessment of microbiological quality of drinking water from household in Bermuda. Can J Microbiol 2008; 54: 495-500. [PubMed] 
18. Fellipe A, Thorsten K, Julio L, Sylvana M, Santos G, Savia G. Water quality and microbial diversity in cisterns from semiarid areas in Brazil. J Water Health 2014; 12: 513-25. [PubMed]

19. Ahmed W, Gardner T, Toze S. Microbiological quality of roof-harvested rainwater and health risks: a review. J Environ Qual 2011; 40: 13-21. [PubMed]
20. Jordan PE, Albert IK, Avanoa HP, Nese IC, Eric JN. Epidemiological investigation of a diarrhea outbreak in the South Pacific Island Nation of Tuvalu during a severe La-Niña associated drought emergency in 2011. Amer J Trop Med Hyg 2017: 96: 576-82. [ajtmh] 